\title{
PENGEMBANGAN PERANGKAT PEMBELAJARAN FISIKA MODEL STRUCTURED INQUIRY UNTUK MENINGKATKAN KETERAMPILAN PEMECAHAN MASALAH SISWA PADA MATERI FLUIDA STATIS
}

\author{
Rohmah Primadani'), Tukiran²), Budi Jatmiko ${ }^{3)}$ \\ ${ }^{1)}$ Mahasiswa Program Studi Pendidikan Sains, Program Pascasarjana Universitas Negeri Surabaya \\ ${ }^{2), 3)}$ Dosen Pascasarjana Prodi Pendidikan Sains Universitas Negeri Surabaya \\ E-mail:rohmahprimadani@gmail.com
}

\begin{abstract}
Abstrak: Kurikulum 2013 menekankan pembelajaran selain pada pencapaian pengetahuan, juga menekankan pada keterampilan siswa dengan memberi ruang yang cukup bagi siswa untuk mengembangkan kreativitas dan kemandirian mereka sehingga memiliki kemampuan berpikir logis, kritis, dan kreatif serta memiliki keterampilan pemecahan masalah. Kurangnya keterampilan pemecahan masalah siswa dapat disebabkan antara lain karena belum adanya perangkat pembelajaran yang khusus dirancang untuk meningkatkan keterampilan pemecahan masalah siswa. Untuk itu dalam penelitian ini dikembangkan perangkat pembelajaran fisika model structured inquiry sebagai usaha meningkatkan keterampilan pemecahan masalah siswa. Pengembangan perangkat pembelajaran menggunakan model 4D dan diujicobakan pada siswa kelas X di SMAN 1 Krian pada semester genap tahun pelajaran 2014/2015. Desain ujicoba perangkat menggunakan One Group Pre-test and Post-test Design. Metode pengumpulan data yang digunakan adalah validasi, tes, observasi, dan angket. Sedangkan teknik analisis data menggunakan analisis deskriptif kuantitatif dan deskriptif kualitatif. Berdasarkan analisis dan pembahasan diperoleh beberapa temuan, yaitu: 1) perangkat pembelajaran yang dikembangkan tergolong valid; 2) keterbacaan BAS dan LKS tergolong tinggi; 3) pada pelaksanaan ujicoba diperoleh RPP terlaksana dengan baik, meskipun masih ada beberapa kendala (waktu untuk mengelola kelas dan kesulitan dalam menggunakan alat ukur); 4) aktivitas siswa yang dominan adalah melaksanakan rencana pemecahan masalah; 5) keterampilan pemecahan masalah siswa setelah pembelajaran meningkat signifikan dengan kategori tinggi; dan 6) respon siswa terhadap pembelajaran model structured inquiry tergolong positif. Berdasarkan hasil analisis dan diskusi penelitian dapat disimpulkan bahwa perangkat pembelajaran yang dikembangkan mempunyai kualitas yang layak digunakan dalam pembelajaran untuk meningkatkan keterampilan pemecahan masalah siswa pada materi fluida statis.
\end{abstract}

Kata kunci: Pengembangan Perangkat, Structured Inquiry, Keterampilan Pemecahan Masalah, Fluida Statis.

Abstract: Curriculum 2013 emphasizes learning not only the achievement of knowledge, but also emphasizes the skills of students by providing sufficient space for students to develop their creativity and independence so that it has the ability to think logical, critical, creative thinkings and have problem solving skills. The lack of student's skill in problem solving may be caused partly because of the lack of teaching materials that are specifically designed to enhance student's skill in problem solving. Therefore in this study it is developed a physics teaching materials based on structured inquiry model as an effort to improve student's skill in problem solving. Development of the teaching materials used 4D models and tried out at class X SMAN 1 Krian in 2014/2015. The materials are tried out using One Group Pre-test and post-test design. Data collection methods was conducted using validation, testing, observation, and questionnaires. Data analysis technique was conducted using quantitative and qualitative descriptive. Based on the data analysis and discussion, it is obtained: 1) teaching materials developed is classified as valid; 2) book and student's worksheet readability has a high category; 3) the implementation of lesson plans is performed well, although there are still several problems (time for managing class and the difficulty is using equipments); 4) dominant activity of students is to implement problem-solving plan; 5) problem solving skills of students after learning increases significantly with high category; and 6) the student's response to the learning model of structured inquiry is classified as positive. Based on the data analysis and discussion, it can be concluded that the developed teaching materials was feasible to be used in learning process to improve student's skill in problem-solving for static fluid.

Keywords: Development Of Teaching Materials, Structured Inquiry, Problem Solving, Static Fluid.

\section{PENDAHULUAN}

Pendidikan adalah usaha sadar dan terencana untuk mewujudkan suasana belajar dan proses pembelajaran agar siswa secara aktif mengembangkan potensi dirinya untuk memiliki kekuatan spiritual keagamaan, pengendalian diri, kepribadian, kecerdasan, akhlak mulia, serta keterampilan yang diperlukan dirinya, masyarakat, bangsa dan negara (Depdikbud, 2003).

Suasana belajar dan proses pembelajaran mempengaruhi hasil belajar siswa. Salah satu hasil 
belajar yang harus dimiliki siswa adalah keterampilan pemecahan masalah.

Berdasarkan studi awal terhadap pembelajaran fisika di SMA Negeri 1 Krian melalui angket siswa dan wawancara terhadap guru diperoleh bahwa pembelajaran tergolong masih monoton dan belum optimal dalam melatihkan keterampilan siswa untuk memecahkan suatu permasalahan. Hal ini dibuktikan dengan hasil tes pemecahan masalah pada siswa kelas XI pada materi Fluida Statis. $93,75 \%$ siswa belum mampu memahami masalah, $100 \%$ siswa belum mampu merencanakan percobaan, dan $87,5 \%$ siswa belum mampu menganalisis data percobaan sekaligus membuat kesimpulan percobaan.

Perangkat pembelajaran fisika di SMA Negeri 1 Krian sudah baik, memenuhi karakteristik perangkat yang baik, serta telah sesuai dengan petunjuk penyusunan perangkat pembelajaran kurikulum 2013, tetapi belum ada perangkat pembelajaran yang khusus bertujuan untuk meningkatkan keterampilan pemecahan masalah siswa. Sehingga perlu dikembangkan perangkat pembelajaran fisika yang bertujuan untuk meningkatkan keterampilan pemecahan masalah siswa.

Orientasi pendidikan adalah terjadinya peningkatan dan keseimbangan antara kompetensi sikap (attitude), keterampilan (skill), dan pengetahuan (knowledge). Salah satu model pembelajaran yang dapat mengakomodir standar proses kurikulum 2013 tersebut adalah model pembelajaran inquiry. Inquiry merupakan pembelajaran yang menanamkan dasar-dasar berpikir ilmiah pada diri siswa. Dalam proses pembelajaran ini siswa lebih banyak belajar sendiri dan mengembangkan kreativitas dalam memecahkan masalah. Inquiry sendiri terbagi dalam lima level (Bonnstetter, 1998). Apabila siswa belum pernah mempunyai pengalaman belajar dengan kegiatan-kegiatan inquiry, maka dapat menggunakan model structured inquiry (inquiry terstruktur).

Pembelajaran inquiry dapat dimulai dengan memberi $\mathrm{problem} / \mathrm{masalah}$ pada siswa. Hal ini dilakukan untuk merangsang dan melatih siswa dalam memecahkan masalah. Siswa lebih cepat lupa jika hanya dijelaskan secara lisan, sebaliknya siswa akan lebih lama mengingat materi jika diberikan contoh, dan memahami jika diberikan kesempatan mencoba memecahkan masalah (Steinbach, 2002 dalam Santyasa, 2005). Guru harus melakukan perubahan paradigma dari cara pandang bahwa mengajar merupakan proses bercerita tentang konsep, menjadi mengajar merupakan proses menyiapkan rangsanganrangsangan kepada siswa untuk melakukan dan memecahkan masalah (Jabot \& Kautz, 2003; Wenning \& Wenning, 2006). Dalam kegiatan pembelajaran, guru Fisika dianjurkan lebih banyak menyediakan contextrich problem daripada context-poor problem Pengembangan Perangkat Pembelajaran Fisika Model Structured Inquiry untuk ...
(Yerushalmi and Magen, 2006). Pernyataan tersebut didukung oleh tiga wawasan berpikir dalam pembelajaran Fisika, yaitu: "(1) to present subject matter is not teaching, (2) to store stuff away in the memory is not learnin, (3) to memorize what is stored away is not proof of understanding" (Nachtigall, 1998 dalam Santyasa, 2005).

Dalam penelitian ini, level inquiry yang digunakan adalah inquiry level structured. Menurut Sadeh \& Zion (2011) dalam inquiry level ini, siswa melakukan penyelidikan dari pertanyaan yang telah diberikan oleh guru. Siswa menerima petunjuk lengkap pada setiap tahap, yang mengarah ke penemuan yang telah ditentukan. Menurut Colburn (2000), dalam structured inquiry guru memberi masalah hands-on untuk diselidiki, prosedur dan bahan-bahan tetapi tidak diberikan hasil yang diharapkan. Siswa menemukan hubungan antara variabel atau generalisasi dari data yang dikumpulkan.

Penelitian yang dilakukan oleh Zakiyah (2011) menunjukkan bahwa penerapan pendekatan inquiry terstruktur berpengaruh terhadap peningkatan keterampilan proses sains siswa. Rata-rata keterampilan proses sains kelompok eksperimen termasuk kategori tinggi $(80,76)$, sedangkan kelompok kontrol termasuk kategori sedang $(58,59)$. Begitu juga penelitian yang dilakukan oleh Ni'mah (2014), diperoleh bahwa penerapan metode inquiry terstruktur dengan media permainan puzzle dapat meningkatkan aktivitas dan hasil belajar IPA siswa kelas IV B SDN Bakalan Krajan I. Penelitian lain menggunakan inquiry terstruktur dilakukan oleh Yaningsih (2014). Hasilnya adalah ada perbedaan yang sangat signifikan dari hasil belajar siswa yang diajar menggunakan strategi pembelajaran inquiry terstruktur dan strategi pembelajaran ekspositori pada materi sistem ekskresi manusia di kelas XI IPA SMA Negeri 2 Lubuk Pakam Tahun Pelajaran 2013/2014.

Menurut Zion \& Mendelovici (2012) dalam structured inquiry siswa menyelidiki pertanyaan yang diberikan guru melalui prosedur yang sudah ditentukan dan menerima pedoman langkah demi langkah secara eksplisit pada setiap tahap yang mengarah ke hasil yang telah ditentukan, mirip dengan mengikuti resep. Siswa terlibat dalam proses penyelidikan ilmu pengetahuan dan mengembangkan keterampilan penyelidikan dasar, seperti melakukan observasi, merumuskan hipotesis, mengumpulkan dan mengorganisir data, membuat kesimpulan, dan mencari solusi.

Tidak berbeda dengan beberapa ahli sebelumnya, Amri dan Ahmadi (2010) menyatakan inquiry dengan latihan terstruktur (Structured science exsperiences) atau inquiry terstruktur merupakan kegiatan inquiry dimana guru menentukan topik, pertanyaan, bahan, dan prosedur sedangkan analisis hasil dan kesimpulan 
dilakukan oleh siswa. Dalam inquiry terstruktur (structured inquiry), guru harus mengemukakan masalah pada siswa untuk diselidiki dan juga prosedur serta alat-alat yang digunakan, tetapi guru tidak memberi tahu hasilnya. Siswa menemukan hubungan antara dua variabel atau generalisasi dari data yang telah terkumpul.

Dari pernyataan-pernyataan tersebut dapat disimpulkan bahwa penekanan dalam penyelidikan terstruktur adalah pada proses penyelidikan yang dimulai dengan mengidentifikasi pertanyaan terkait, melalui pengumpulan data, dan berakhir dengan kesimpulan berdasarkan bukti yang sesuai.

Keterampilan pemecahan masalah yang menjadi pokok penelitian ini merupakan situasi yang tidak memiliki solusi atau strategi solusi yang diketahui (Kennedy, Tipps, and Johnson, 2008). Masalah merupakan sebuah situasi, kuantitatif atau kualitatifa, yang dihadapi oleh individu atau kelompok individu, yang membutuhkan penyelesaian, dimana individu melihat tidak ada jalan yang jelas untuk solusinya (Krulik \& Rudnick, 1989).

Lebih lanjut Krulik \& Rudnick menjelaskan perbedaan antara pertanyaan, latihan, dan masalah: (a) pertanyaan merupakan sebuah situasi yang dapat diatasi dengan hanya mengingat dan memori. Sementara (b) latihan merupakan situasi yang melibatkan drill dan latihan untuk mengendalikan keterampilan yang telah dipelajari sebelumnya. Dan (c) masalah adalah sebuah situasi yang memerlukan analisis dan sintesis pengetahuan yang dipelajari sebelumnya untuk menyelesaikannya.

Dalam sumber lain, Moursund (2005) menyatakan bahwa seseorang dianggap memiliki atau mengalami masalah bila menghadapi empat kondisi berikut: 1) Kesulitan dalam memahami dengan jelas kondisi atau situasi yang sedang terjadi; 2) Kesulitan dalam memahami dengan jelas tujuan yang diharapkan; 3) Memiliki berbagai tujuan untuk menyelesaikan masalah, tetapi tidak dapat mengarahkan menjadi satu tujuan penyelesaian; 4) Kesulitan dalam memahami sekumpulan sumber daya yang dapat dimanfaatkan untuk mengatasi situasi yang terjadi sesuai dengan tujuan.

Keterampilan memecahkan masalah IPA merupakan keterampilan proses sians (Nur, 2009), antara lain: merumuskan masalah; merumuskan hipotesis; merencanakan eksperimen; melaksanakan eksperimen; menganilisis data; dan menyimpulkan data. Sedangkan menurut Polya (1973), solusi soal pemecahan masalah disajikan dalam empat fase penyelesaian, yaitu: 1) Memahami masalah, kegiatan yang dilakukan pada langkah ini adalah membuat gambar atau ilustrasi jika memungkinkan, mencari kasus yang khusus dan mencoba memahami masalah yang sederhana; 2)
Merencanakan penyelesaian, kegiatan yang dapat dilakukan pada langkah ini adalah merencanakan solusi secara sistematis, menentukan apa yang akan dilakukan, bagaimana melakukannya, dan hasil yang diharapkan; 3) Mencari solusi dari masalah, kegiatan yang dapat dilakukan pada langkah ini adalah menjalankan prosedur yang telah dibuat pada langkah sebelumnya untuk mendapatkan penyelesaian; dan 4) Melakukan pengecekan kembali prosedur dan hasil penyelesaian, kegiatan yang dapat dilakukan pada langkah ini adalah menganalisis dan mengevaluasi apakah prosedur yang diterapkan dan hasil yang diperoleh benar, apakah ada prosedur lain yang lebih efektif, apakah prosedur yang dibuat dapat digunakan untuk menyelesaikan masalah yang sejenis, atau apakah prosedur dapat dibuat generalisasinya.

Berdasarkan pendapat-pendapat di atas, keterampilan pemecahan masalah adalah keterampilan yang dimiliki oleh siswa untuk memecahkan suatu masalah melalui metode dan sikap ilmiah berupa merumuskan masalah, menyusun hipotesis, merencanakan prosedur pemecahan masalah, melakukan eksperimen, dan menyimpulkan hasil. Dari berbagai indikator pemecahan masalah sebagaimana diuraikan di atas, peneliti menyimpulkan bahwa terdapat empat indikator penting dalam penelitian ini untuk mengukur keterampilan pemecahan masalah siswa, antara lain:

a. Memahami masalah

b. Merencanakan penyelesaian masalah.

c. Menyelesaikan masalah sesuai rencana

d. Melakukan pengecekan kembali

Berdasarkan uraian di atas, peneliti melakukan penelitian dengan judul "Pengembangan Perangkat Pembelajaran Fisika Model Structured Inquiry untuk Meningkatkan Keterampilan Pemecahan Masalah Siswa pada Materi Fluida Statis". Tujuan penelitian ini adalah memperoleh perangkat pembelajaran fisika model structured inquiry yang layak untuk meningkatkan keterampilan pemecahan masalah siswa pada materi fluida statis.

\section{METODE PENELITIAN}

Penelitian ini merupakan penelitian pengembangan karena mengembangkan perangkat pembelajaran fisika dengan model pembelajaran structured inquiry berupa Silabus, Rencana Pelaksanaan Pembelajaran (RPP), Buku Ajar Siswa (BAS), Lembar Kerja Siswa (LKS), dan Instrumen penilaian.

Subjek dalam penelitian ini adalah perangkat pembelajaran fisika model structured inquiry. Perangkat yang dikembangkan kemudian diujicobakan pada siswa kelas X-A1, X-A2, dan X-A3 SMAN 1 Krian tahun pelajaran 2014-2015. Pelaksanaan uji coba 
perangkat pembelajaran dilakukan selama lima kali pertemuan, dengan rincian: satu pertemuan untuk pretest, tiga pertemuan KBM, dan satu pertemuan untuk post-test.

Secara umum pelaksanaan penelitian dilakukan dalam dua tahap, yaitu tahap pengembangan perangkat pembelajaran dan tahap implementasi perangkat pembelajaran. Pada tahap pengembangan, perangkat dikembangkan dengan menggunakan model 4-D yang direduksi menjadi model 3-D. (diadopsi dari Thiagarajan, Dorothy, and Melvyn, 1974)

Desain uji coba perangkat menggunakan rancangan eksperimen one group pretest-posttest design, yang dapat digambarkan sebagai berikut:

\section{$\mathbf{U}_{1} \mathbf{X} \mathbf{U}_{2}$}

Keterangan:

$\mathbf{U}_{1}$ : Uji awal (pretest) untuk mengetahui keterampilan pemecahan masalah siswa terhadap materi fluida statis sebelum pembelajaran structured inquiry.

$\mathbf{U}_{2}$ : Uji akhir (posttest) untuk mengetahui keterampilan pemecahan masalah siswa terhadap materi fluida statis sesudah pembelajaran structured inquiry.

$\mathrm{X}$ : perlakuan pembelajaran menggunakan perangkat pembelajaran model structured inquiry yang telah divalidasi

Teknik pengumpulan data dalam penelitian ini, yaitu:

1. Perangkat pembelajaran yang telah dikembangkan untuk dinilai dalam lembar validasi oleh 3 validator.

2. Data keterlaksanaan pembelajaran diperoleh melalui observasi. Keterlaksanaan pembelajaran diamati oleh dua orang pengamat selama pelaksanaan RPP.

3. Data aktivitas siswa diperoleh melalui observasi. Aktivitas siswa diamati oleh dua orang pengamat selama proses KBM.

4. Data kendala pembelajaran diperoleh melalui observasi.

5. Data keterbacaan BAS dan LKS diperoleh dengan cara memberikan angket keterbacaan BAS dan LKS pada siswa setelah proses KBM.

6. Data respon siswa diperoleh dengan cara memberikan angket respon siswa setelah semua proses KBM.

7. Data keterampilan pemecahan masalah siswa diperoleh dengan memberikan pre-test dan post-test pada siswa.

Teknik analisis data dalam penelitian ini adalah sebagai berikut:

1. Analisis Kevalidan Perangkat Pembelajaran

Perangkat pembelajaran (Silabus, RPP, BAS, LKS, dan Instrumen penilaian) ditelaah oleh validator untuk memberikan penilaian terhadap kelayakan penggunaannya. Adapun kriteria perangkat pembelajaran dapat dilihat pada Tabel 1 berikut.

Tabel 1. Kriteria Perangkat Pembelajaran

\begin{tabular}{|l|l|l|}
\hline Interval Skor & $\begin{array}{l}\text { Kategori } \\
\text { Penilaian }\end{array}$ & $\begin{array}{l}\text { Kategori } \\
\text { kevalidan }\end{array}$ \\
\hline $3,60 \leq S V \leq 4,00$ & Sangat Baik & Valid \\
\hline $2,60 \leq S V \leq 3,59$ & Baik & Cukup Valid \\
\hline $1,60 \leq S V \leq 2,59$ & Kurang Baik & Kurang valid \\
\hline $1,00 \leq S V \leq 1,59$ & Tidak Baik & Tidak valid \\
\hline
\end{tabular}

2. Analisis Kepraktisan Perangkat Pembelajaran

a. Analisis Keterlaksanaan Pembelajaran

Data keterlaksanaan pembelajaran yang diperoleh selanjutnya dianalisis secara deskriptif kuantitatif dengan rumus:

$$
P=\frac{\sum F}{\sum N} \times 100 \%
$$

Keterangan:

$$
\begin{aligned}
& \mathrm{P}=\text { Persentase keterlaksanaan RPP } \\
& \sum K_{=\text {Jumlah aspek yang terlaksana }} \\
& \sum N_{=} \text {Jumlah keseluruhan aspek yang diamati }
\end{aligned}
$$

b. Analisis Aktivitas Siswa

Analisis data aktivitas siswa dalam kegiatan pembelajaran dilakukan untuk mengetahui aktivitas siswa dalam proses pembelajaran. Data yang diperoleh dianalisis menggunakan analisis deskriptif kuantitatif dengan bentuk diagram (Suharsimi, 2009). Berdasarkan rata-rata penilaian dua pengamat pada tiap-tiap kategori yang diamati, untuk setiap rencana pembelajaran akan ditentukan persentasenya (P), dengan persamaan:

$$
P=\left(\frac{\text { Rata }- \text { Rata dari Dua Pengamat }}{\text { Jumlah Pengamatan }}\right) \times 100 \%
$$

c. Analisis Kendala dalam KBM dan Alternatif Solusi

Kendala selama pelaksanaan KBM dianalisis dengan analisis deskriptif kualitatif, yaitu pengamat dan peneliti memberikan catatan kendala yang terjadi pada pelaksanaan pembelajaran sebanyak tiga pertemuan disertai dengan alternatif solusi.

d. Analisis Keterbacaan BAS dan LKS

Tingkat keterbacaan merupakan ukuran dari pemahaman siswa terhadap BAS dan LKS. Analisis keterbacaan BAS dan LKS dilakukan menggunakan analisis deskriptif kuantitatif dan analisis deskriptif kualitatif. Data diperoleh berupa angka-angka kuantitatif dan selanjutnya dilakukan penerjemahan dari angka-angka tersebut dalam suatu pernyataaan sesuai dengan batasan-batasan yang telah disusun sebelumnya (Suharsimi, 2009).

3. Analisis Kefektifan Perangkat Pembelajaran

a. Analisis Data Respon Siswa

Data yang diperoleh dianalisis menggunakan analisis deskriptif kuantitatif dengan penyajian data berupa grafik/diagram (Suharsimi, 2009). Data respon 
siswa dianalisis melalui persentase dengan persamaan sebagai berikut:

$$
P=\frac{\Sigma N}{\Sigma N} x 100 \%
$$

dengan:

$$
\begin{array}{ll}
\mathrm{P} & : \text { Persentase }(\%) \\
\Sigma \mathrm{K} & : \text { Jumlah jawaban respon } \\
\Sigma \mathrm{N} & : \text { Jumlah respon }
\end{array}
$$

b. Analisis Tes Keterampilan Pemecahan Masalah

Analisis data tes dilakukan untuk mengetahui peningkatan keterampilan pemecahan masalah siswa. Nilai pre-test dan post-test diperoleh melalui rumus:

$$
N=\frac{j u m \text { lah shĭor yang diperoleh siswa }}{\text { shor maks imal }} \times 100
$$

Selanjutnya nilai pre-test dan post-test siswa diuji sebagai berikut:

1). Uji t

Untuk menganalisis apakah terdapat perbedaan signifikan antara hasil pretest dan posttest siswa pada setiap kelas digunakan uji $\mathrm{t}$ berpasangan dengan rumus sebagai berikut:

$$
t=\frac{d}{s / \sqrt{n}}
$$

(Kothari, 2004)

Dengan $\mathrm{t}=$ nilai uji $\mathrm{t}$

$$
\begin{aligned}
& \bar{d}=\text { rata-rata perbedaan } \\
& \mathrm{s}=\text { standart deviasi perbedaan } \\
& \mathrm{n}=\text { jumlah siswa }
\end{aligned}
$$

Pengujian hipotesis:

Ho: tidak terdapat perbedaan signifikan antara rata-rata hasil pretest dan postest siswa.

$\mathrm{H}_{1}$ : terdapat perbedaan signifikan antara ratarata hasil pretest dan postest siswa.

Dengan kriteria pengujian:

Ho diterima jika $t_{\text {hitung }}<\mathrm{t}_{\text {tabel}}$, maka $\mathrm{H}_{1}$ ditolak.

Ho ditolak jika $t_{\text {hitung }}>\mathrm{t}_{\text {tabel, }}$, maka $\mathrm{H}_{1}$ diterima.

Sebelum dilakukan uji t, harus dilakukan uji normalitas terlebih dahulu, uji $\mathrm{t}$ dapat dilakukan jika nilai pretest dan nilai postest terdistribusi normal.

2). Uji N-gain

Untuk menganalisis besarnya pengaruh pembelajaran terhadap keterampilan pemecahan masalah siswa, dilakukan analisis statistik inferensial berupa analisis $N$-gain score dengan rumus sebagai berikut:

$$
\begin{aligned}
& (g)=\text { spost }-5 p r e \\
& N\langle g\rangle=\frac{5 p o s t-5 p r e}{5 m a x-5 p r t}
\end{aligned}
$$

Dengan $(\mathrm{g}) \quad=$ nilai gain

$$
\begin{aligned}
& \mathrm{N}\langle g\rangle=\text { gain ternormalisasi } \\
& \mathrm{S}_{\text {post }}=\text { nilai } \text { post-test } \\
& \mathrm{S}_{\text {pre }}=\text { nilai } \text { pre-test } \\
& \mathrm{S}_{\max }=\text { nilai maksimal }
\end{aligned}
$$

Hasil perhitungan selanjutnya diinterpretasi berdasarkan interpretasi $N$-gain score menurut Hake (1999) yaitu: berkategori tinggi untuk $\mathrm{N}\langle g\rangle>0,7$; berkategori sedang untuk $0,3 \leq \mathrm{N}\langle g\rangle \leq 0,7$; dan berkategori rendah untuk $\mathrm{N}\langle g\rangle<0,3$.

3). Uji ANOVA

Untuk menganalisis apakah terdapat perbedaan ratarata $\mathrm{N}^{\langle g\rangle}$ pada ketiga kelas ujicoba digunakan analisis varian (ANOVA) dengan rumus:

$$
F=\frac{M S_{F}}{M S_{E}}
$$

dengan

$$
\begin{array}{ll}
\mathrm{F} & =\text { nilai } \mathrm{F} \text { hitung } \\
\mathrm{MSp} & =\text { varian antar kelompok } \\
\mathrm{MSE} & =\text { varian dalam kelompok }
\end{array}
$$

Pengujian hipotesis:

Ho $: \mu 1=\mu 2=\mu 3$, tidak ada perbedaan antara ratarata $\mathrm{N}\langle\mathrm{g}\rangle$.

$\mathrm{H}_{1}$ : ada salah satu $\mu$ yang berbeda dengan yang lain.

Dengan kriteria pengujian:

Jika $F_{\text {hitung }}>\mathrm{F}_{\text {tabel }}$ : Ho ditolak

Jika $\mathrm{F}_{\text {hitung }}<\mathrm{F}_{\text {tabel }}:$ Ho diterima

Sebelum dilakukan uji ANOVA, harus dilakukan uji normalitas dan uji homogenitas terlebih dahulu. Uji ANOVA dapat dilakukan jika data terdistribusi normal dan homogen.

\section{HASIL PENELITIAN DAN DISKUSI}

Hasil pengembangan perangkat pembelajaran fisika model pembelajaran stuctured inquiry untuk meningkatkan keterampilan pemecahan masalah siswa yang dikembangkan telah valid untuk digunakan dalam pembelajaran. Hasil validasi perangkat pembelajaran oleh validator dapat dilihat pada Gambar 2. berikut.

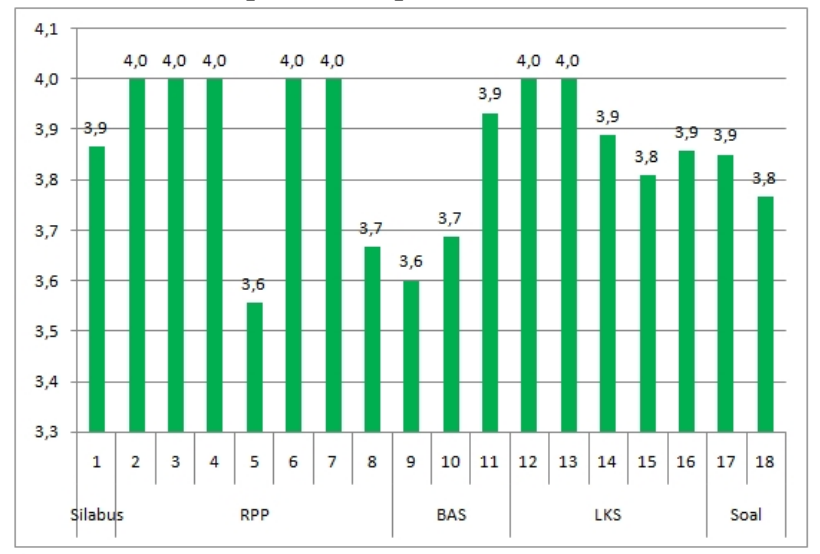

Gambar 2. Hasil Validasi Perangkat Pembelajaran

Keterangan:
1. Semua aspek
2. Identitas
3. Tujuan Pembelajaran
4. Alat dan sumber belajar 
5. Pendekatan, model dan metode Pembelajaran

6. Kegiatan pembelajaran

7. Waktu

8. Bahasa

9. Komponen Kelayakan Isi

10. Komponen Bahasa

11. Komponen Penyajian

12. Aspek Identitas

13. Aspek Petunjuk

14. Aspek Format

15. Aspek Bahasa

16. Aspek Isi

17. Validasi isi

18. Bahasa dan penulisan soal

Gambar 2 menunjukkan bahwa silabus berkategori valid dengan skor 3,9. Rata-rata skor sebesar 3,9 menunjukkan bahwa silabus telah memenuhi syarat kelengkapan silabus. Dalam Permendikbud No. 65 tahun 2013 tentang standar proses pendidikan dasar dan menengah, silabus terdiri dari: identitas mata pelajaran; identitas sekolah meliputi nama satuan pendidikan dan kelas; kompetensi inti; kompetensi dasar; materi pokok memuat fakta, konsep, prinsip dan prosedur yang relevan; pembelajaran meliputi kegiatan yang dilakukan oleh pendidik dan siswa; penilaian meliputi proses pengumpulan dan pengolahan informasi untuk menentukan pencapaian hasil belajar siswa; alokasi waktu; sumber belajar berupa buku, media cetak dan elektronik, alam sekitar atau sumber lain yang relevan (Depdikbud, 2013).

Rencana pelaksanaan pembelajaran (RPP) yang dikembangkan berkriteria valid dengan skor rata-rata sebesar 3,9. Hal ini menunjukkan RPP yang dikembangkan cukup baik dalam segi konstruk dan isi. RPP dikembangkan dari silabus untuk mengarahkan kegiatan pembelajaran siswa dalam upaya mencapai Kompetensi Dasar (KD). Dalam menyusun RPP hendaknya memperhatikan prinsip-prinsip sebagai berikut: Perbedaan individual siswa antara lain kemampuan awal, tingkat intelektual, bakat, potensi, minat, motivasi belajar, kemampuan sosial, emosi, gaya belajar, kebutuhan khusus, kecepatan belajar, latar belakang budaya, norma, nilai, dan/atau lingkungan siswa; Partisipasi aktif siswa; Berpusat pada peserta didik untuk mendorong semangat belajar, motivasi, minat, kreativitas, inisiatif, inspirasi, inovasi dan kemandirian; Pengembangan budaya membaca dan menulis yang dirancang untuk mengembangkan kegemaran membaca, pemahaman beragam bacaan, dan berekspresi dalam berbagai bentuk tulisan; Pemberian umpan balik dan tindak lanjut RPP memuat rancangan program pemberian umpan balik positif, penguatan, pengayaan, dan remedi; Penekanan pada keterkaitan dan keterpaduan antara KD, materi pembelajaran, kegiatan pembelajaran, indikator pencapaian kompetensi, penilaian, dan sumber belajar dalam satu keutuhan pengalaman belajar; Mengakomodasi pembelajaran tematik-terpadu, keterpaduan lintas mata pelajaran, lintas aspek belajar, dan keragaman budaya; dan penerapan teknologi informasi dan komunikasi secara terintegrasi, sistematis, dan efektif sesuai dengan situasi dan kondisi (Depdiknas, 2013).

Berdasarkan penilaian validator Buku Ajar Siswa (BAS) yang telah disusun berkategori valid dengan skor sebesar 3,7. Lembar Kegiatan Siswa (LKS) yang telah disusun berkategori valid dengan skor rata-rata 3,9. Pada validasi soal diperoleh bahwa soal berkategori valid dengan skor sebesar 3,9. Hasil pengamatan keterlaksanaan perangkat pembelajaran yang dikembangkan telah praktis untuk digunakan.Hasil pengamatan keterlaksanaan RPP yang dilakukan oleh dua orang guru mata pelajaran fisika disajikan pada Gambar 3, 4, dan 5 sebagai berikut.

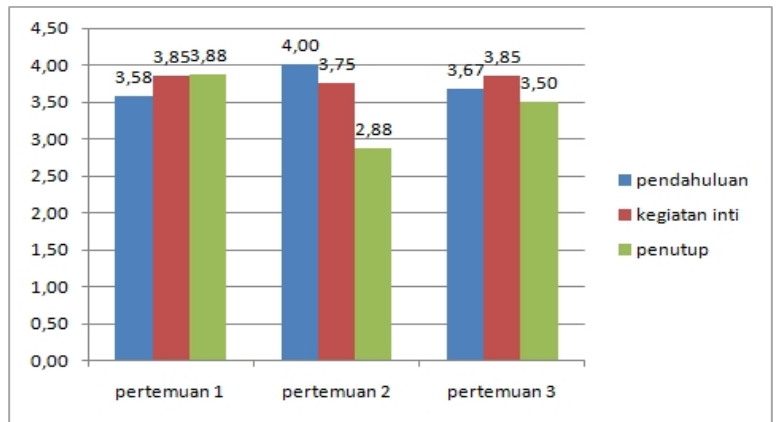

Gambar 3. Hasil Pengamatan Keterlaksanaan RPP di kelas X-A1

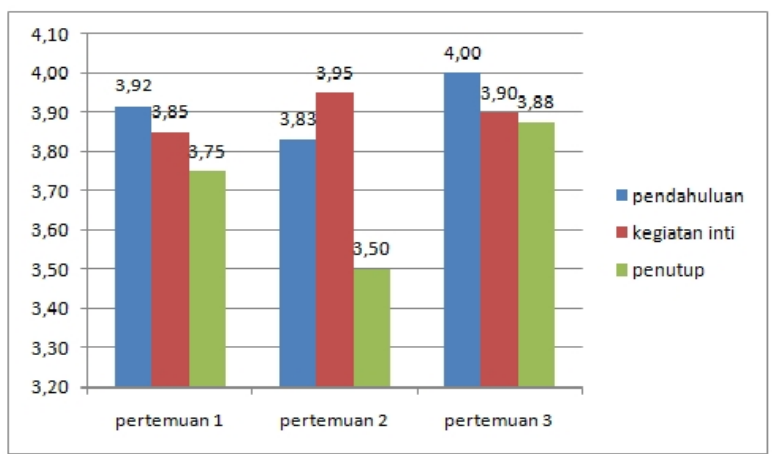

Gambar 4. Hasil Pengamatan Keterlaksanaan RPP di Kelas X-A2

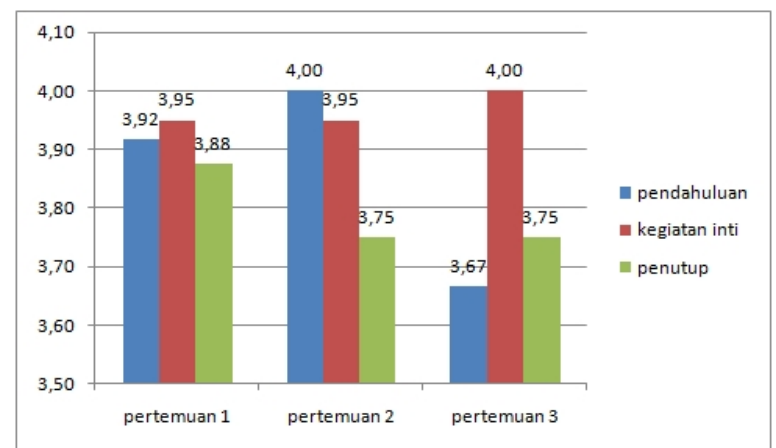

Gambar 5. Hasil Pengamatan Keterlaksanaan RPP di Kelas X-A3 
Pada tahap pendahuluan, terdapat fase pendahuluan yaitu guru memotivasi siswa dengan menyajikan fenomena, meminta siswa mengamati gambar, membimbing siswa mengidentifikasi masalah, memberi kesempatan siswa untuk bertanya, memberikan kesempatan siswa mengajukan rumusan masalah, dan menyampaikan materi yang akan dipelajari. Pada kegiatan inti guru memberikan kesempatan siswa menyampaikan hipotesis, membimbing siswa menentukan hipotesis yang relevan, membagi siswa dalam kelompok, membagikan LKS, dan membimbing siswa dalam eksperimen. Pada fase penutup guru meminta siswa mengerjakan soal latihan serta mengumpulkannya.

Berdasakan Gambar 3, 4 dan 5 diperoleh bahwa rata-rata aspek yang terlaksana sebesar $100 \%$ dengan skor rata-rata 3,8. Rata-rata pelaksanaan pembelajaran sebesar 3,8 menunjukkan bahwa pembelajaran berlangsung dengan baik dan sesuai rencana pembelajaran. Tingginya tingkat keterlaksanaan dalam pengelolaan pembelajaran menandakan bahwa guru telah memperhatikan beberapa hal penting yang dapat mempengaruhi hasil belajar siswa. Beberapa hal yang harus diperhatikan oleh guru dalam pengelolaan pembelajaran adalah pengaturan posisi duduk siswa, volume dan intonasi suara guru harus baik, selain itu kecepatan dan kemampuan belajar siswa juga harus diperhatikan (Depdiknas, 2013).

Selama KBM berlangsung guru dan siswa sangat antusias terhadap pembelajaran. Hal ini dipengaruhi oleh penggunaan model pembelajaran structured inquiry merupakan hal baru bagi siswa. KBM dilaksanakan sesuai sintaks yang dibuat dan cenderung berpusat pada siswa. Dengan model pembelajaran structured inquiry diharapkan aktivitas siswa bersifat hands-on activity, sehingga siswa memperoleh pengetahuan dari kegiatan yang dilakukan sendiri. Hal ini sesuai tujuan pembelajaran model structured inquiry yang mana diharapkan siswa berperan aktif dalam proses pembelajaran. Menurut Zion \& Mendelovici (2012) dalam structured inquiry siswa menyelidiki pertanyaan yang diberikan guru melalui prosedur yang sudah ditentukan, dan menerima pedoman langkah demi langkah secara eksplisit pada setiap tahap, yang mengarah ke hasil yang telah ditentukan, mirip dengan mengikuti resep.

Besarnya skor keterlaksanaan pembelajaran menunjukkan peran aktif siswa meningkat dalam proses pembelajaran. Hal ini didukung oleh penelitian Ruswana (2013) yang menyatakan bahwa penggunaan model pembelajaran structured inquiry meningkatkan sikap positif siswa dalam pembelajaran. Inquiry merupakan suatu model pembelajaran dimana guru memberi keleluasaan siswa untuk melibatkan diri dalam proses pembelajaran semaksimal mungkin untuk mencari pengetahuan baru.

Aktivitas siswa selama proses pembelajaran yang diamati oleh dua orang guru mata pelajaran fisika disajikan pada Gambar 6.

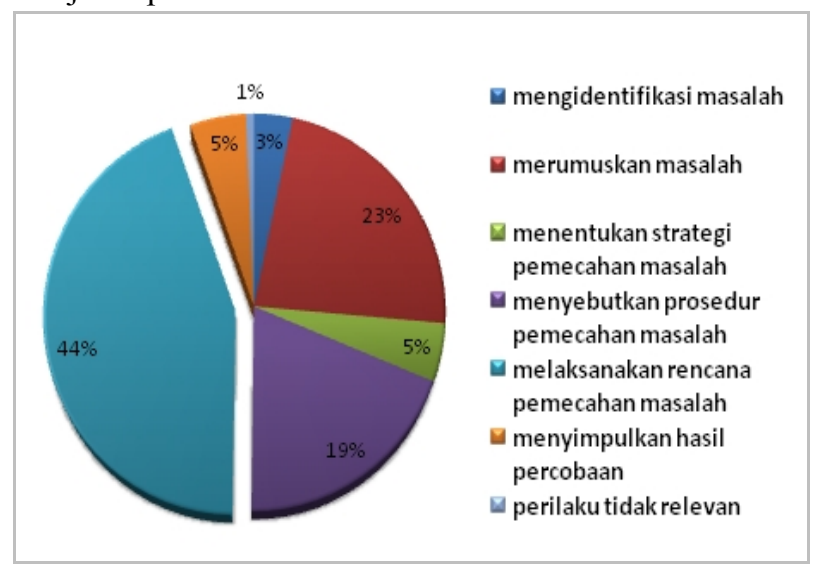

Gambar 6. Persentase Aktivitas Siswa

Berdasarkan Gambar 6 didapatkan bahwa aktivitas yang paling dominan pada siswa adalah melaksanakan rencana pemecahan masalah yang mencapai $44 \%$. Hal ini sesuai dengan skenario yang direncanakan dalam RPP model pembelajaran structured inquiry. Pembelajaran structured inquiry menekankan pada proses siswa dalam menemukan pengetahuan. Menurut Zion \& Mendelovici (2012) dalam structured inquiry siswa melakukan penyelidikan terhadap pertanyaan yang diberikan guru melalui prosedur yang sudah ditentukan. Siswa terlibat dalam proses penyelidikan ilmu pengetahuan dan mengembangkan keterampilan penyelidikan dasar, seperti melakukan observasi, merumuskan hipotesis, mengumpulkan dan mengorganisir data, membuat kesimpulan, dan mencari solusi. Kesesuaian antara model pembelajaran dengan aktivitas siswa tidak lepas dari keterlaksanaan tahaptahap pembelajaran yang telah dirancang. Terlaksananya tahap-tahap pembelajaran dengan baik sangat mempengaruhi aktivitas siswa dalam pembelajaran.

Dengan model pembelajaran structured inquiry, siswa diajak untuk belajar memahami materi fluida statis melalui eksperimen yang ditujukan untuk meningkatkan keterampilan pemecahan masalah siswa. Dalam pelaksanaannya, pembelajaran bukan tanpa kendala,. Beberapa kendala yang masih ditemui adalah pengaturan waktu, pembelajaran dilakukan di laboratorium, sehingga perlu waktu lebih untuk menyiapkan siswa menuju laboratorium serta menyiapkan alat. Selain itu, keterampilan siswa dalam menggunakan alat-pun menjadi kendala dalam pembelajaran. Penggunaan BAS dan LKS perlu dilihat apakah keduanya mempunyai keterbacaan yang tinggi. Berikut grafik keterbacaan BAS dan LKS. 


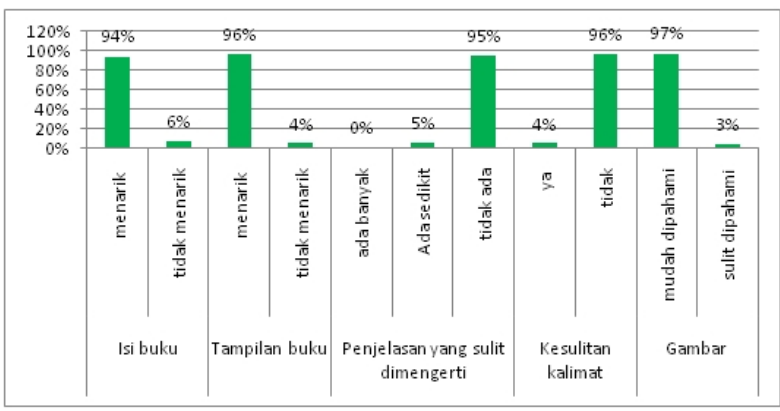

Gambar 7. Keterbacaan BAS

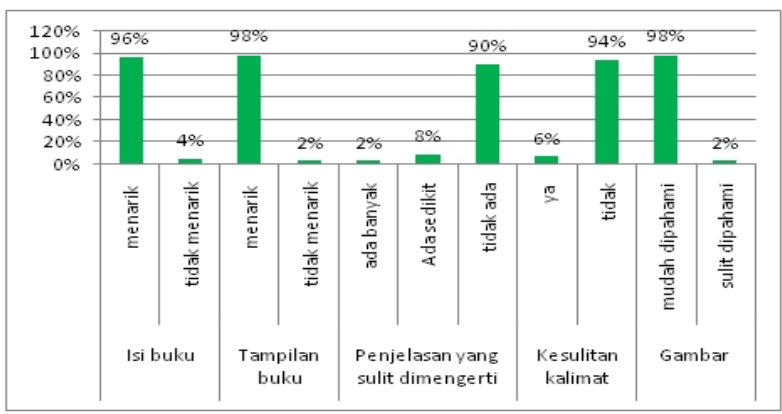

Gambar 8. Keterbacaan LKS

BAS dan LKS digunakan untuk meningkatkan efisiensi dan efektivitas pembelajaran. BAS dan LKS juga digunakan untuk membantu proses belajar siswa. Dengan BAS dan LKS yang baik diharapkan hasil belajar siswa akan meningkat. Berdasarkan Gambar 7 dan Gambar 8 diperoleh bahwa BAS dan LKS mempunyai tingkat keterbacaan yang tinggi yaitu di atas $90 \%$. Untuk melihat keefektifan penggunaan perangkat pembelajaran dapat dilihat dari segi respon siswa setelah pembelajaran yang disajikan pada Gambar 9-13.

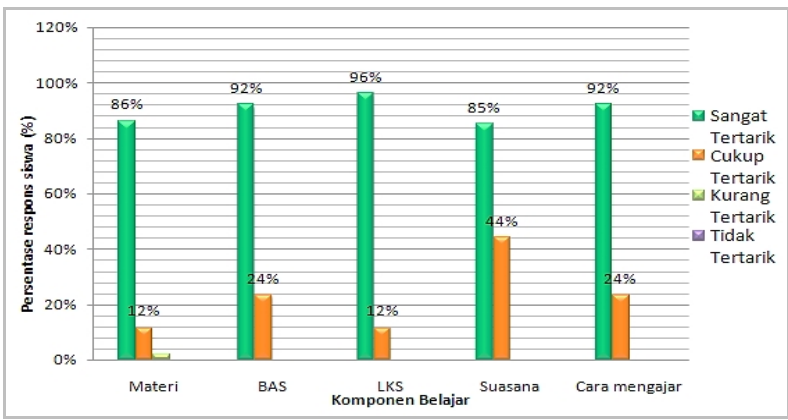

Gambar 9. Respon Siswa terhadap Komponen Belajar

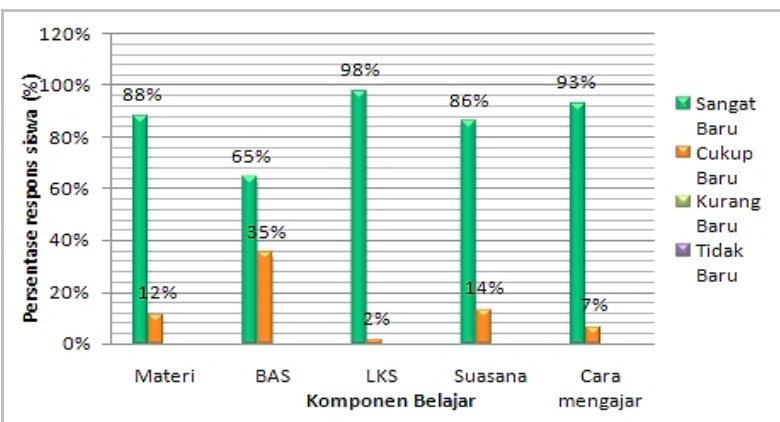

Gambar 10. Respon Siswa terhadap Kebaruan Komponen Belajar

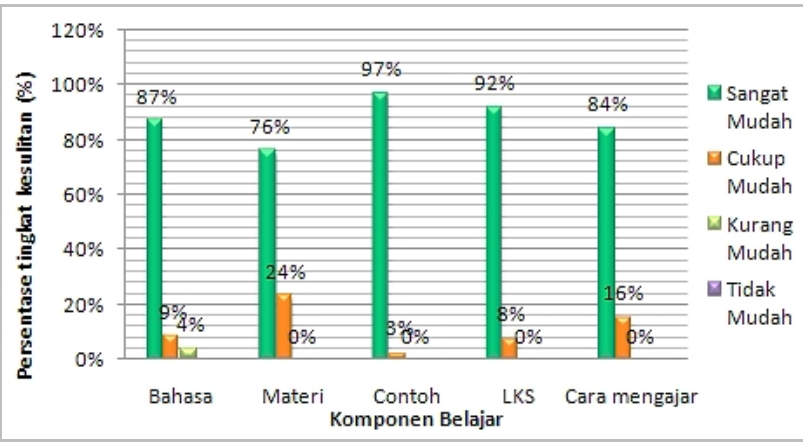

Gambar 11. Respon Siswa terhadap Kemudahan Pemahaman Komponen Belajar

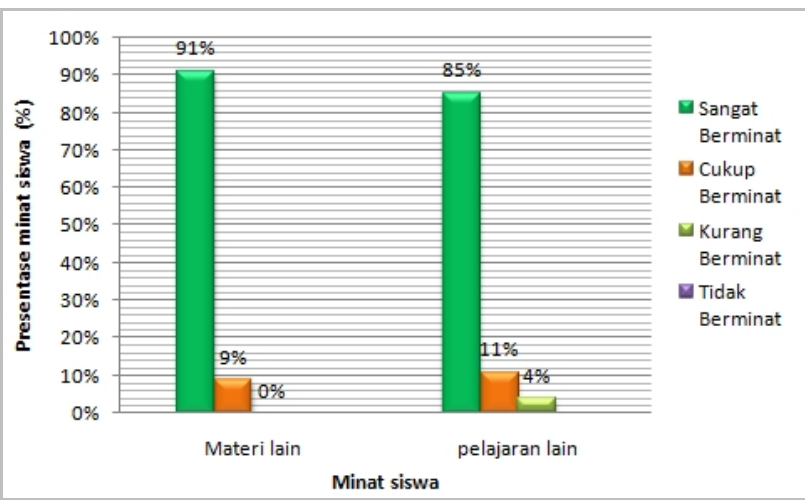

Gambar 12. Respon Siswa terhadap Minat Menggunakan Komponen Belajar

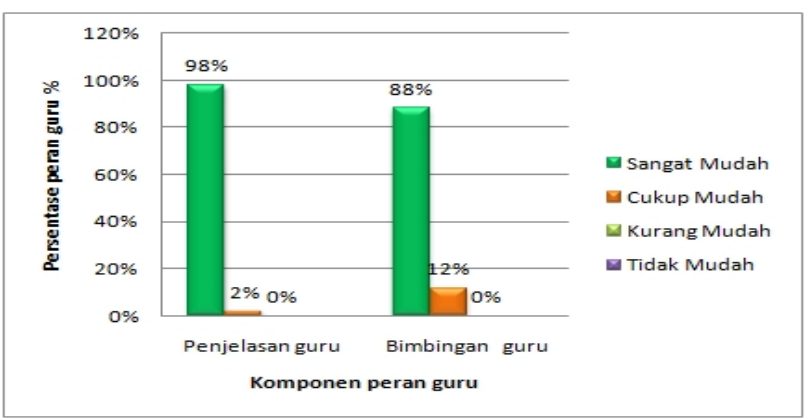

Gambar 13. Respon Siswa terhadap Peran Guru dalam Pembelajaran

Berdasarkan gambar 9-13 diperoleh bahwa siswa merespon positif penggunaan model structured inquiry dalam pelaksanaan pembelajaran. $86 \%$ siswa menyatakan sangat tertarik dengan materi yang disajikan oleh guru, 92\% dan 96\% siswa tertarik pada penggunaan BAS dan LKS. Hal ini mengindikasikan siswa senang dengan pembelajaran serta perangkat yang digunakan dalam pembelajaran. Tingginya respon siswa terhadap komponen pembelajaran, tingkat kebaruan, kemudahan dalam pemahaman serta peran guru dalam pembelajaran membuat siswa antusias untuk mengikuti pembelajaran.

Antusiasme siswa untuk mengikuti pembelajaran dipengaruhi oleh kelebihan model yang digunakan. Model pembelajaran structured inquiry mempunyai kelebihan antara lain: menerapkan pengetahuan dalam situasi yang berbeda; mendapatkan kemampuan untuk 
belajar dan menerapkan materi pengetahuan; mengaitkan pengetahuan baru dengan pengetahuan sehari-hari dan; memperoleh dan menganalisa informasi menjadi lebih terampil (Zakiyah, 2011). Dengan kelebihan tersebut siswa lebih antusias dalam mengikuti pembelajaran.

Secara keseluruhan, siswa memberikan respon positif terhadap pelaksanaan pembelajaran dengan model pembelajaran structured inquiry. Respon positif ini menunjukkan bahwa siswa antusias dengan pembelajaran yang disajikan. Hal ini dapat memotivasi siswa untuk meningkatkan perhatian dan membuat mereka terlibat dalam pengalaman pembelajaran yang menyenangkan dan bermakna (Nur, 2009).

Hasil analisis $N$-gain score pada tes keterampilan pemecahan masalah siswa antara pre-test dan post-test diperlihatkan pada Tabel 2 .

Tabel 2. Analisis $N$-Gain Score Tes Keterampilan Pemecahan Masalah

\begin{tabular}{|l|c|c|c|c|c|c|c|c|c|}
\hline \multirow{2}{*}{ No. } & \multicolumn{3}{|c|}{ X-A1 } & \multicolumn{3}{|c|}{ X-A2 } & \multicolumn{3}{|c|}{ X-A3 } \\
\cline { 2 - 11 } & Pre & Post & N<g $>$ & Pre & Post & N<g $>$ & Pre & Post & N $<$ g $>$ \\
\hline 1 & 22 & 85 & 0,81 & 12 & 88 & 0,87 & 13 & 87 & 0,85 \\
\hline 2 & 22 & 92 & 0,89 & 7 & 95 & 0,95 & 13 & 88 & 0,87 \\
\hline 3 & 15 & 90 & 0,88 & 12 & 83 & 0,81 & 15 & 90 & 0,88 \\
\hline 4 & 13 & 97 & 0,96 & 20 & 92 & 0,90 & 17 & 83 & 0,80 \\
\hline 5 & 17 & 88 & 0,86 & 15 & 88 & 0,86 & 12 & 85 & 0,83 \\
\hline 6 & 23 & 92 & 0,89 & 8 & 87 & 0,85 & 12 & 85 & 0,83 \\
\hline 7 & 23 & 97 & 0,96 & 8 & 88 & 0,87 & 18 & 98 & 0,98 \\
\hline 8 & 15 & 93 & 0,92 & 10 & 85 & 0,83 & 20 & 98 & 0,98 \\
\hline 9 & 17 & 85 & 0,82 & 13 & 85 & 0,83 & 23 & 98 & 0,98 \\
\hline 10 & 15 & 87 & 0,84 & 15 & 100 & 1,00 & 18 & 100 & 1,00 \\
\hline 11 & 23 & 92 & 0,89 & 13 & 93 & 0,92 & 22 & 98 & 0,98 \\
\hline 12 & 17 & 95 & 0,94 & 13 & 87 & 0,85 & 12 & 85 & 0,83 \\
\hline 13 & 18 & 93 & 0,92 & 15 & 92 & 0,90 & 20 & 97 & 0,96 \\
\hline 14 & 12 & 97 & 0,96 & 18 & 93 & 0,92 & 20 & 95 & 0,94 \\
\hline 15 & 15 & 87 & 0,84 & 15 & 98 & 0,98 & 18 & 97 & 0,96 \\
\hline 16 & 17 & 98 & 0,98 & 13 & 93 & 0,92 & 18 & 95 & 0,94 \\
\hline 17 & 15 & 88 & 0,86 & 13 & 97 & 0,96 & 18 & 95 & 0,94 \\
\hline 18 & 15 & 92 & 0,90 & 17 & 97 & 0,96 & 18 & 95 & 0,94 \\
\hline 19 & 18 & 100 & 1,00 & 15 & 92 & 0,90 & 18 & 95 & 0,94 \\
\hline 20 & 15 & 97 & 0,96 & 10 & 100 & 1,00 & 18 & 95 & 0,94 \\
\hline 21 & 15 & 92 & 0,90 & 17 & 92 & 0,90 & 17 & 93 & 0,92 \\
\hline 22 & 22 & 98 & 0,98 & 18 & 93 & 0,92 & 17 & 92 & 0,90 \\
\hline 23 & 17 & 88 & 0,86 & 13 & 88 & 0,87 & 10 & 85 & 0,83 \\
\hline 24 & 8 & 85 & 0,84 & 15 & 88 & 0,86 & 17 & 93 & 0,92 \\
\hline 25 & 10 & 85 & 0,83 & 12 & 95 & 0,94 & 17 & 92 & 0,90 \\
\hline 26 & 13 & 95 & 0,94 & 15 & 98 & 0,98 & 15 & 97 & 0,96 \\
\hline 27 & 27 & 90 & 0,86 & 13 & 85 & 0,83 & 15 & 92 & 0,90 \\
\hline 28 & 15 & 92 & 0,90 & 18 & 97 & 0,96 & 15 & 93 & 0,92 \\
\hline 29 & 10 & 90 & 0,89 & 13 & 92 & 0,90 & 15 & 93 & 0,92 \\
\hline 30 & 10 & 88 & 0,87 & 10 & 97 & 0,96 & 13 & 92 & 0,90 \\
\hline 31 & 12 & 88 & 0,87 & 15 & 87 & 0,84 & 15 & 90 & 0,88 \\
\hline 32 & 8 & 83 & 0,82 & 15 & 93 & 0,92 & 13 & 88 & 0,87 \\
\hline 33 & 17 & 97 & 0,96 & 13 & 90 & 0,88 & 13 & 88 & 0,87 \\
\hline 34 & 10 & 97 & 0,96 & 12 & 85 & 0,83 & 10 & 83 & 0,81 \\
\hline Min & & & 0,81 & & & 0,81 & & & 0,80 \\
\hline Rax & & & 1,00 & & & 1,00 & & & 1,00 \\
\hline & & & 0,90 & & & 0,90 & & & 0,91 \\
\hline
\end{tabular}

Nilai keterampilan pemecahan masalah siswa menggambarkan seberapa besar keterampilan pemecahan masalah yang dimiliki siswa sebelum dan sesudah dilakukannya proses pembelajaran. Berdasarkan uji-t diperoleh bahwa terdapat perbedaan signifikan rata-rata hasil pretest dan posttest siswa pada setiap kelas. Signifikansi ini selain dipengaruhi oleh pelaksanaan pembelajaran yang sesuai rencana, juga dipengaruhi oleh kualitas perangkat penilaian hasil belajar yang baik. Hasil penelitian ini mendukung penelitian terdahulu yang menyatakan penggunaan model pembelajaran inquiri terstruktur dapat meningkatkan ketuntasan siswa (Hafsyah, Prihandono, dan Yushardi, 2012). Penelitian ini juga diperkuat oleh hasil penelitian yang menyatakan terdapat hubungan yang signifikan antara model pembelajaran inquiry terstruktur dan hasil belajar siswa (Sudirman, 2012). Sehingga dapat disimpulkan model pembelajaran stuctured inquiry dapat meningkatkan keterampilan pemecahan masalah siswa.

Selanjutnya analisis dilakukan dengan mencari besar pengaruh pembelajaran terhadap keterampilan pemecahan masalah siswa melalui analisis $N$-gain score. Berdasarkan tabel 2 diketahui bahwa rata-rata $N$-gain score kelas X-A1, X-A2, dan X-A3 masingmasing sebesar 0,90, 0,90, dan 0,91 dengan kategori tinggi. Tingginya $\mathrm{N}$-gain score dapat disebabkan beberapa hal, diantaranya pelaksanaan pembelajaran yang sesuai dengan rencana dan kesesuaian permasalahan dengan model pembelajaran yang diterapkan. Tingginya $N$-gain score menunjukkan bahwa penggunaan model pembelajaran structured inquiry dapat meningkatkan keterampilan pemecahan masalah siswa. Hal ini didukung oleh penelitian yang menyatakan bahwa model pembelajaran inkuiri terstruktur dapat meningkatkan penguasaan konsep siswa (Sugianti, 2011). Dalam pembelajaran siswa belajar melalui tahapan-tahapan pemecahan masalah, sehingga siswa mempunyai pengalaman dalam memecahkan masalah. Dalam sebuah penelitian dinyatakan pembelajaran Peer Instruction with Structured Inquiry (PISI) dapat meningkatkan kemampuan pemecahan masalah matematis siswa (Ruswana, 2013). Selain meningkatkan kemampuan pemecahan masalah siswa, pembelajaran inkuiri terstruktrur juga meningkatkan kemampuan berpikir kritis siswa (Usmianingsih, 2011).

Berdasarkan uji ANOVA terhadap $N$-gain score diperoleh bahwa tidak terdapat perbedaan signifikan rata-rata antara kelas X-A1, X-A2, dan X-A2. Sehingga disimpulkan bahwa pembelajaran mempunyai pengaruh yang sama pada setiap kelas. Berdasarkan rata-rata $N$ gain score dapat dilihat bahwa $\mathrm{N}$-gain score untuk kelas X-A3 lebih tinggi dari pada kelas yang lain. Hal ini dapat disebabkan karena antusiasme siswa pada saat 
pelaksanaan pembelajaran. Berdasarkan data aktivitas siswa, siswa kelas X-A3 mempunyai aktivitas melaksanakan rencana pemecahan masalah tertinggi dibandingkan kelas lain yaitu sebesar $46 \%$. Selain itu, pada pengamatan keterlaksanaan RPP dapat dilihat bahwa untuk kelas X-A3 memiliki rata-rata keterlaksaan lebih tinggi dibandingkan kelas lain yaitu sebesar 3,92 dari skala 4. Hal ini didukung oleh penelitian yang menyatakan ada hubungan positif antara aktivitas siswa dengan hasil belajar siswa (Hardianti, 2013).

Berdasarkan analisis pencapaian indikator tentang keterampilan pemecahan masalah siswa diperoleh bahwa keterampilan siswa yang masih perlu ditingkatkan adalah keterampilan siswa dalam menyusun langkah penyelesaian masalah. Indikator menjelaskan prosedur percobaan termasuk indikator sulit, hal ini dibuktikan untuk indikator tersebut siswa mendapat nilai lebih rendah daripada indikator yang lain. Penyebabnya adalah selain siswa harus memahami langkah demi langkah proses pemecahan masalah secara menyeluruh, juga dipengaruhi dengan pembagian tugas dalam kelompok yang kurang baik, sehingga terdapat siswa yang cenderung pasif dan tidak mendapat bagian tugas dalam kelompok .

Melalui model pembelajaran structured inquiry siswa memperoleh pengetahuan keterampilan pemecahan masalah. Dalam model pembelajaran structured inquiry siswa menyelidiki pertanyaan yang diberikan guru melalui prosedur yang sudah ditentukan, melakukan penyelidikan, dan mengembangkan keterampilan penyelidikan dasar (Zion \& Mendelovici, 2012). Keberhasilan pembelajaran dalam meningkatkan keterampilan pemecahan masalah siswa merupakan cerminan terlaksananya pembelajaran dengan baik dan sesuai skenario. RPP terlaksana dengan baik dengan rata-rata keterlaksanaan sebesar $100 \%$. Meskipun terdapat kendala berupa ketersediaan waktu belajar, tetapi tidak mempengaruhi hasil belajar khususnya keterampilan pemecahan masalah siswa. Hal ini disebabkan karena kendala yang dihadapi bukan kendala esensial dalam terlaksananya pembelajaran dan dapat diatasi.

Selain itu aktivitas siswa yang dikehendaki seperti menentukan strategi pemecahan masalah, dan melaksanakan rencana pemecahan masalah dilaksanakan oleh siswa dengan baik. Menurut Gulo (2002) dalam Hafsyah, Prihandono, dan Yushardi (2012) inquiry mempunyai tahap-tahap antara lain: merumuskan masalah, merumuskan hipotesis, mengumpulkan bukti, menguji hipotesis dan menarik kesimpulan. Berdasarkan tahap-tahap proses inquiry tersebut, wajar jika aktivitas siswa didominasi oleh aktivitas berkaitan dengan proses eksperimen. Penelitian yang dilakukan oleh Ross (2000) disimpulkan bahwa inquiry learning-based experiment di laboratorium memberikan hasil positif berupa kemampuan siswa memahami teori tanpa adanya miskonsepsi. Inquiry learning-based experiment lebih menekan siswa untuk menggunakan keterampilan berpikir tingkat tinggi. Hal ini mendukung keberhasilan pembelajaran structured inquiry dalam meningkatkan keterampilan pemecahan masalah siswa.

Keberhasilan meningkatkan keterampilan pemecahan masalah siswa merupakan efek dari penerapan RPP, BAS, dan LKS dalam proses pembelajaran. Penggunaan media tidak dapat diabaikan, media yang digunakan dapat memotivasi siswa dalam proses pembelajaran. Motivasi tidak hanya penting untuk menjadikan siswa terlibat dalam kegiatan pembelajaran, tetapi juga menentukan seberapa banyak siswa dalam menyerap informasi yang disajikan pada mereka.

\section{KESIMPULAN}

\section{A. Simpulan}

Berdasarkan temuan pada bab sebelumnya diperoleh simpulan secara umum bahwa perangkat pembelajaran fisika model structured inquiry yang dikembangkan adalah layak digunakan dalam pembelajaran untuk meningkatkan keterampilan pemecahan masalah siswa pada materi fluida statis.

\section{B. Saran}

Beberapa saran sebagai salah satu solusi alternatif dari beberapa kendala yang ditemui dalam penelitian ini adalah sebagai berikut:

1. Mengingat kendala yang dihadapi saat eksperimen biasanya adalah masalah pengelolaan waktu, diperlukan kontrol waktu dan persiapan yang lebih baik.

2. Pengintensifan pembelajaran pada bab besaran dan pengukuran harus ditingkatkan, agar siswa dalam eksperimen dapat menggunakan alat ukur dengan baik.

\section{REFERENSI}

Amri, S. \& Ahmadi, I.K. (2010) Konstruksi Pengembangan Pembelajaran: Pengaruhnya terhadap Mekanisme dan Praktik Kurikulum, Jakarta: Prestasi Pustaka raya.

Bonnstetter, R.J. (1998). "Inquiry: Learning from the Past with an Eye on the Future". Electronic Journal of Science Education. Vol. 3 No. 1.

Colburn, A. (2000). An Inquiry Primer. California: California State University Long Beach.

Depdikbud. (2003). Undang-Undang No. 20 Tahun 2003, tentang Sistem Pendidikan Nasional. Jakarta : Depdiknas.

Depdikbud. (2013). Permendikbud No. 65 Tahun 2013 Tentang Standar Proses. Jakarta: Depdikbud. 
Hafsyah, S.N., Prihandono, T. \& Yushardi. (2012). "Penerapan Model Inkuiri Terstruktur dengan Media Virtual-Lab pada Pembelajaran Fisika di SMP”. Jurnal Pembelajaran Fisika. Vol. 1 No. 2, hal. 158-164.

Hake, R.R. (1999). Analyzing Change/Gain Scores. Dept. of Physics Indiana University. Diakses dari http://www.physics.indiana.edu pada tanggal 30 November 2014.

Hardianti, R.D. (2013). Hubungan antara Aktivitas Belajar dengan Menggunakan Metode Group Investigation Terhadap Hasil Belajar Kognitif IPS Siswa Keas VIII SMP Negeri 1 Cawas (Skripsi tidak dipublikasikan). Universitas Negeri Yogyakarta, Yogyakarta.

Jabot, M. \& Kautz, C.H. (2003). "A model for preparing preservice physics teachers using inquiry-based methods". Journal of Physics Teacher Education (Online). Vol. 1 No. 4, pp. 25-31.

Kothari, C.R. (2004). Research Methodology:Methods and Techniques. New Delhi: New Age International (P) Ltd.,Publishers.

Marsound, D. (2005). Improving Math Education in Elementary School: A Short Book for Teachers. Oregon: University of Oregon.

Ni'mah, E.A. (2014). Penerapan Metode Inkuiri Terstruktur dengan Media Permainan Puzzle untuk Meningkatkan Aktivitas dan Hasil Belajar IPA Siswa Kelas IVB SDN Bakalan Krajan I Kota Malang Tahun Ajaran 2013/2014 (Tesis tidak dipublikasikan). Universitas Negeri Malang.

Nur, M. (2009). Keterampilan-Keterampilan Proses Sains. PSMS Surabaya.Unipress unesa.

Polya, G. (1973). How to Solve it: An New Aspect of Mathematical Method, Second Edition. New Jersey: Princeton University Press.

Ross, R. (2000). Inquiry-based Experiments in the Introductory Physics Laboratory. Kansas : IEEE

Ruswana, A. M. (2013). Penerapan Pembelajaran Peer Instruction with Structured Inquiry (PISI) untuk Meningkatkan Kemampuan Pemahaman dan Pemecahan Masalah Matematis Siswa (Tesis tidak dipublikasikan). Universitas Pendidikan Indonesia, Bandung.

Sadeh, I. \& Zion, M. (2011). "Which Type of Inquiry Project Do High School Biology Students Prefer: Open or Guided?". Res Sci Educ Journal. Vol. 42, pp. 831-848.

Santyasa, I.W. (2005). Pengembangan Pemahaman Konsep dan Kemampuan Pemecahan Fisiska Bagi Siswa SMA dengan Pemberdayaan Model
Perubahan Konseptual Berseting Investigasi Kelompok (Penelitian tidak dipublikasikan). Universitas Pendidikan Ganesha, Bali.

Sudirman, M. (2012). Pengaruh Model Pembelajaran Inkuiri Terstruktur Terhadap Hasil Belajar Fisika Siswa pada Konsep Wujud Zat yang Bernuansa Nilai (Skripsi tidak dipublikasikan). UIN Syarif Hidayatullah, Jakarta.

Sugianti, D. (2011). Pengaruh Pertanyaan Produktif dalam Model Pembelajaran Inkuiri Terstruktur Terhadap Penguasaan Konsep Struktur Jaringan Tumbuhan (Skripsi tidak dipublikasikan). UIN Syarif Hidayatullah, Jakarta.

Suharsimi, A. (2009). Dasar-dasar Evaluasi Pendidikan. Jakarta: Bumi Aksara.

Thiagarajan, S., Dorothy G.S., \& Melvyn I.S. (1974). Instructional Development for training of Exceptional Children a Sourcebook. Bloomington: Center for Innovation on the Teaching the Handicaped

Usmianingsih, N. (2011). Pengaruh Pembelajaran Inkuiri Terstruktur Terhadap Kemampuan Berpikir Kritis Siswa SMP pada Subkonsep Pencemaran Udara (Skripsi tidak diterbitkan). Universitas Pendidikan Indonesia, Bandung.

Wenning, C.J. \& Wenning, R.E. (2006). "A generic model for inquiry-oriented labs in postsecondary introductory physics". Journal of Physics Teacher Education (Online). Vol. 3 No. 3, pp. 24-28.

Yaningsih, F. (2014). Perbedaan Hasil Belajar Siswa yang Diajar Menggnakan Strategi Pembelajaran Inkuiri Terstruktur dengan Strategi Pembelajaran Ekspositori pada Materi Sistem Ekskresi Manusia di Kelas XI SMA Negeri 2 Lubuk Pakam Tahun Pembelajaran 2013/2014 (Skripsi tidak dipublikasikan). Universitas Negeri Medan.

Yerushalmi, E. \& Magen, E. (2006). "Same old problem, new name? Alerting students to the nature of the problem-solving process". Physics Education. Vol. 41 No. 2, pp. 161-167.

Zakiyah, N. (2011). Pengaruh Pendekatan Inkuiri Terstruktur Terhadap Keterampilan Proses Sains Siswa pada Konsep Sistem Pernapasan Manusia (Skripsi tidak dipublikasikan). Universitas Negeri Syarif Hidayatullah, Jakarta.

Zion, M. \& Mendelovici, R. (2012). "Moving from structured to open inquiry: Challenges and limits". Science Education International. Vol. 23 No.4, pp. 383-399. 